\title{
A new locality of Pilosella cymosa (Asteraceae) in Poland
}

Artur Pliszko

A new locality of Pilosella cymosa (Asteraceae) in Poland. - Acta Mus. Siles. Sci. Natur., 64: 215 $218,2015$.

\begin{abstract}
In June 2013, a new locality of nationally vulnerable plant species Pilosella cymosa was discovered in the town of Suwałki, NE Poland (the ATPOL cartogram unit FB08). The plant grows on roadside verge and its population consists of several hundred flowering individuals.
\end{abstract}

Key words: Hieracium cymosum, Pilosella cymosa, distribution, red list, Poland.

\section{Introduction}

Pilosella cymosa (L.) F. W. Schultz \& Sch. Bip. (三Hieracium cymosum L.) (Asteraceae) is a European-temperate species distributed across the continent except Portugal, Spain, Iceland, Ireland, the United Kingdom, Belgium, and the Netherlands (Bräutigam \& Greuter 2007-2009, Zając \& Zając 2009). It is characteristically found in calcareous xerothermic grasslands of the order Festucetalia valesiacae, on heliophilous and thermophilous forest fringes of the alliance Geranion sanguinei, and in thermophilous oak forests of the order Quercetalia pubescenti-petraeae (Chrtek 2004, Matuszkiewicz 2008).

In Poland, P. cymosa is treated as H. cymosum (Mirek et al. 2002, Zając \& Zając 2009). It is a rare species known from several dozen localities regarding the ATPOL cartogram method (Buliński 2000, Kwiatkowski 2000, 2015, Zając \& Zając 2001, Smoczyk 2010, Kalinowski 2013, Kurzac et al. 2013, Oklejewicz 2013, Pliszko 2014). A large decrease in the number of its localities has been observed in recent decades (Zarzycki et al. 2002). It is included in the Red list of the vascular plants in Poland, and is classified as a vulnerable species (Zarzycki \& Szeląg 2006). In some regions it is ranked higher, for example, in Central Poland as an endangered species (Jakubowska-Gabara \& Kucharski 1999) and in Lower Silesia as a critically endangered species (Kącki et al. 2003).

\section{Characteristics of the new locality and population}

A new locality of Pilosella cymosa was found in 6 June 2013 in the town of Suwałki, NE Poland (GPS coordinates: $54^{\circ} 7^{\prime} 25,8^{\prime \prime} \mathrm{N}, 22^{\circ} 57^{\prime} 3,36^{\prime \prime} \mathrm{E}$ ). According to the ATPOL cartogram method (Zając 1978) presented site is located within the unit FB08 (Fig. 1). The plant was noticed growing on roadside verge near the junction between Armii Krajowej Street and Prymasa Stefana Wyszyńskiego Street (Fig. 2-3). This open mesic habitat is mainly occupied by plant species typical of meadow communities of the order Arrhenatheretalia elatioris (Matuszkiewicz 2008), i.e. Campanula patula, Dactylis glomerata, Festuca pratensis, and Poa pratensis. Population of P. cymosa consists of several hundred flowering individuals dispersed over an area of about 150 $\mathrm{m}^{2}$.

\section{Discussion}

Pilosella cymosa is a very rare species in the Suwałki Region as well in north-eastern Poland. It has been reported from Turówka Stara in the Western Suwałki Lakeland (Pliszko 2014) and from Ordów island in the Wigry National Park (Jutrzenka-Trzebiatowski et al. 2002). The presence of P. cymosa in the town of Suwałki was confirmed in 2014-2015, and 


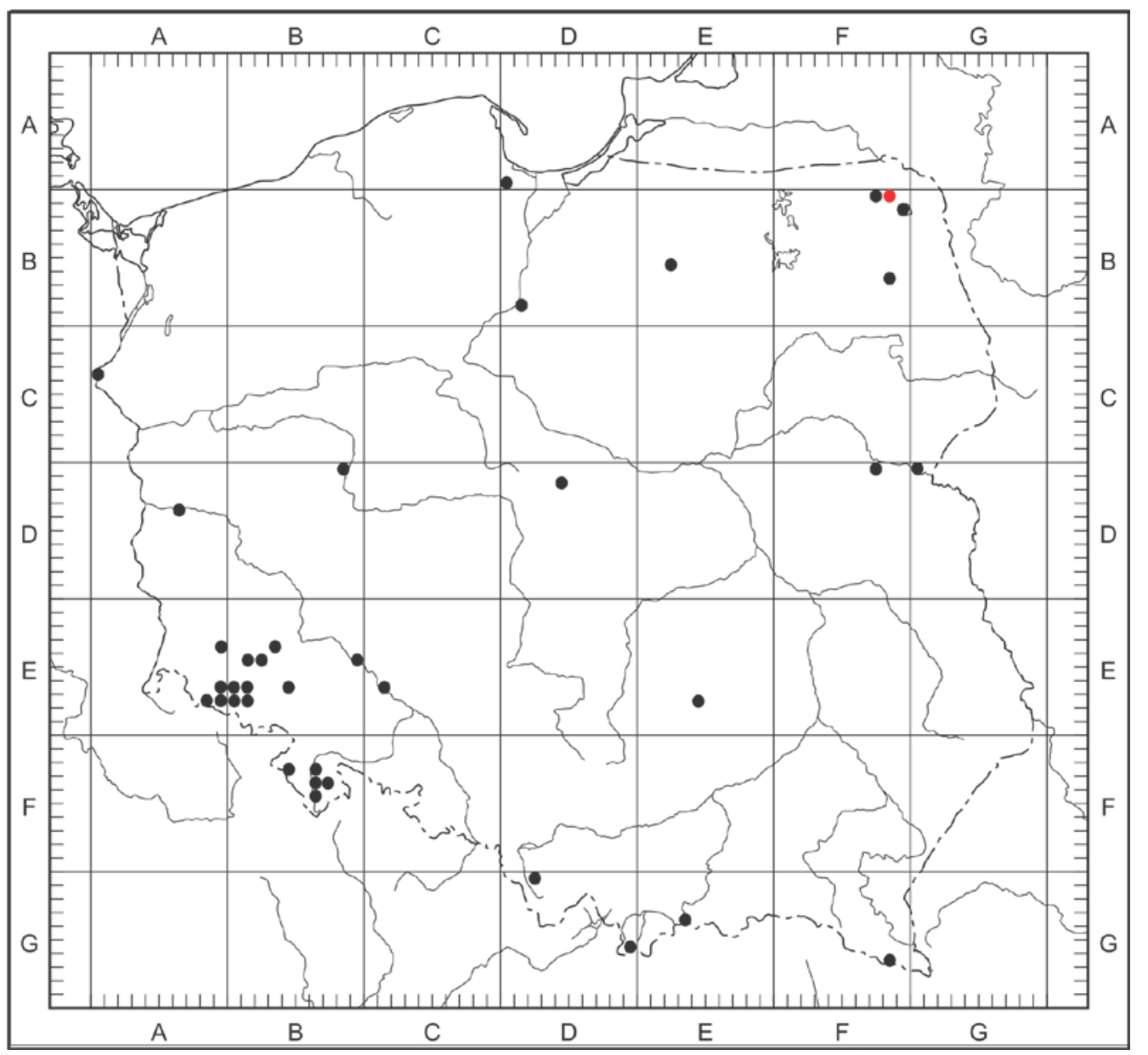

Fig 1: Distribution of Pilosella cymosa in Poland (the ATPOL cartogram grid of $10 \mathrm{~km} \times 10 \mathrm{~km}$ square units): - - known localities (after Buliński 2000, Kwiatkowski 2000, 2015, Zając \& Zając 2001, JutrzenkaTrzebiatowski et al. 2002, Smoczyk 2010, Kalinowski 2013, Kurzac et al. 2013, Oklejewicz et al. 2013, Pliszko 2014); - new locality.

after two years from the date of its discovery the size of its population did not significantly change. The vegetation on the roadside verge where $P$. cymosa occurs is regularly mowed, thus the light conditions are stable. A newly discovered population is not currently threatened with extinction, however, it should be monitored.

In Poland, P. cymosa is usually found in low numbers (Kwiatkowski 2000, Szeląg 2000, Smoczyk 2010, Kalinowski 2013, Kurzac et al. 2013, Oklejewicz et al. 2013) in xerothermic grasslands, dry mesic meadows, pastures, oak forests, and on roadside verges. Moreover, as many other closely related species (Křišt'álová et al. 2010), it thrives in urban areas. The map of distribution included in this paper (Fig. 1) needs to be updated using herbarium data. It should be also mentioned that a new taxonomic treatment of Hieracium in Poland is required according to Bräutigam \& Greuter (2007).

Acknowledgement: I would like to thank Professor Zbigniew Szeląg for revision on herbarium specimens of Pilosella cymosa.

\section{References}

Bräutigam S. \& Greuter W. 2007. A new treatment of Pilosella for the Euro-Mediterranean flora. - Willdenowia 37: 123-137. 


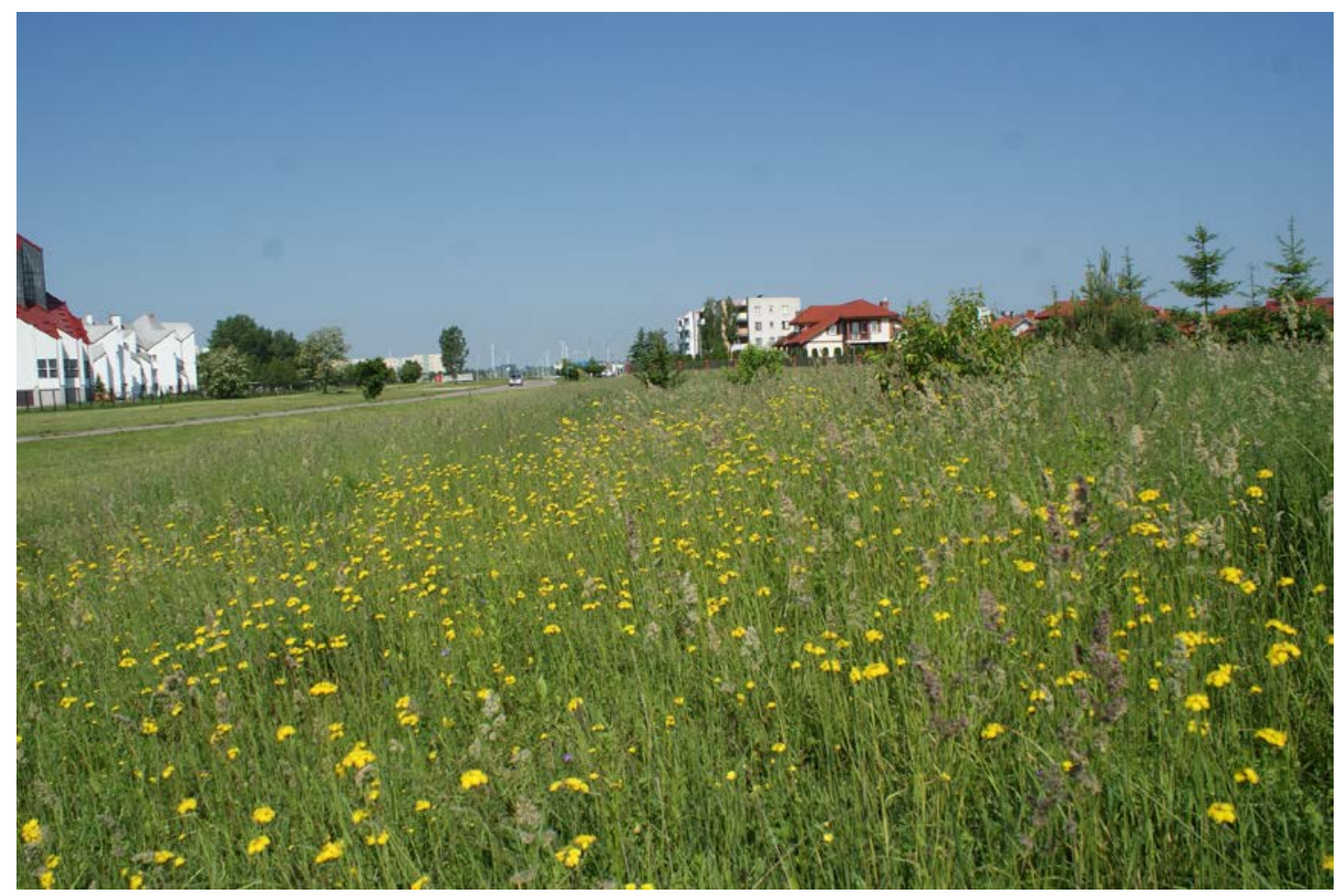

Fig 2: Pilosella cymosa on roadside verge in the town of Suwałki (Photo by A. Pliszko, 6 June 2013).

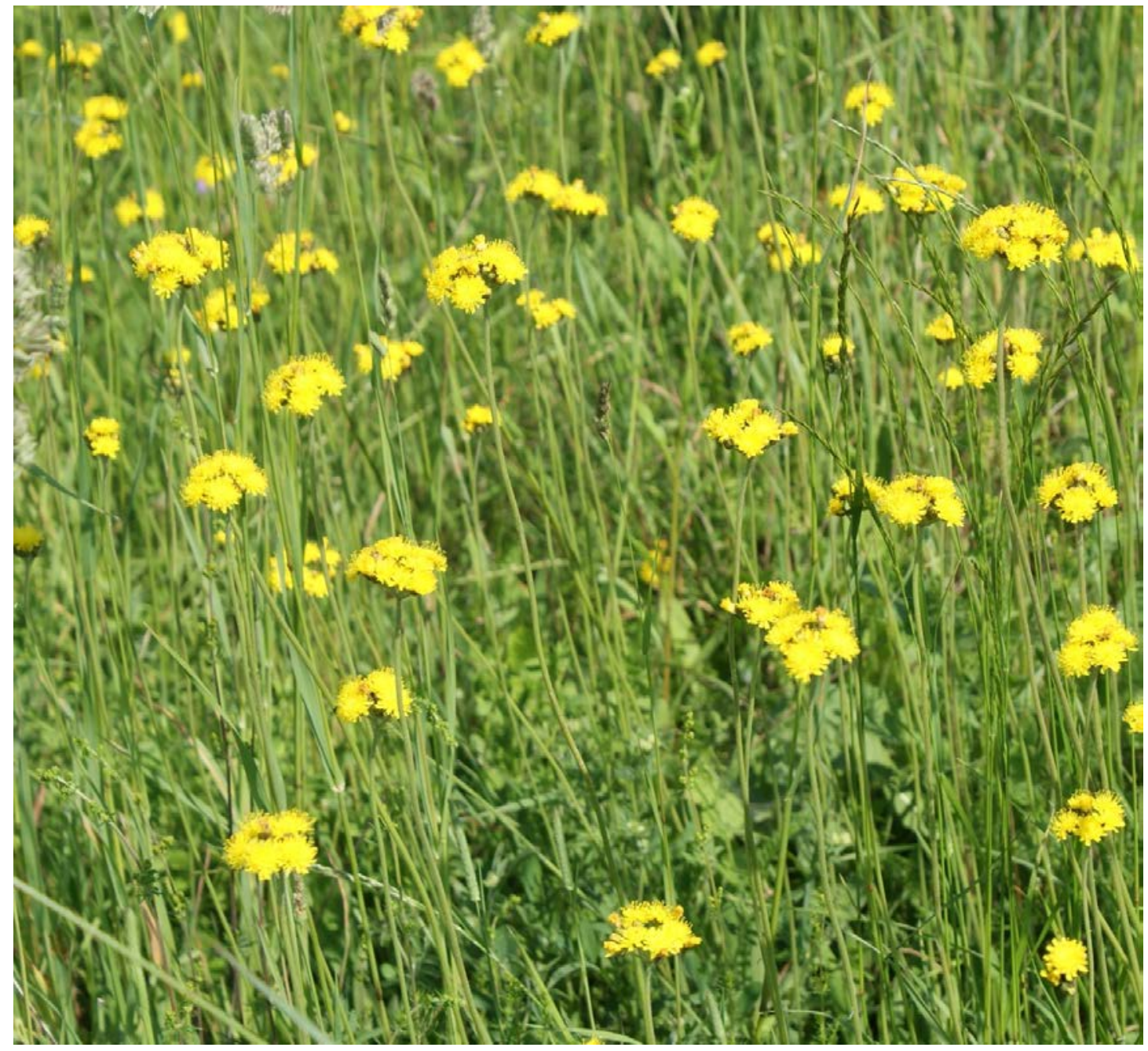

Fig 3: Flowering Pilosella cymosa in the town of Suwałki (Photo by A. Pliszko, 6 June 2013). 
- (2007-2009): Pilosella. In: Greuter W. \& Raab-Straube E. von (eds.): Compositae. Euro+Med Plantbase the information resource for Euro-Mediterranean plant diversity. - ww2.bgbm.org/euroPlusMed [visited 21.10.2015].

Buliński N. (2000): Vascular plants of xerothermic swards and their surroundings in Gdańsk Orunia. - Acta Bot. Cassub. 1: 57-66.

Chrtek J. (2004): Hieracium L. - jestřábník. pp. 540-701. In: Slavík B. \& Štěpánková J. (eds): Květena Českě Republiky 7. Academia, Praha, 767 pp.

Jakubowska-Gabara J. \& Kucharski L. (1999): Ginące i zagrożone gatunki flory naczyniowej zbiorowisk naturalnych i półnaturalnych Polski Środkowej. - Fragm. Florist. Geobot. Polon. 6: 55-74.

Jutrzenka-Trzebiatowski A., Szarejko T. \& Dziedzic J. (2002): Walory florystyczne wybranych obiektów badań geobotanicznych Wigierskiego Parku Narodowego. - Acta Botanica Warmiae et Masuriae 2: 6392.

Kalinowski P. (2013): Rzadkie rośliny naczyniowe Podlasia Nadbużańskiego - cz. 2. Gatunki siedlisk leśnych i wodnych. - Fragm. Florist. Geobot. Polon. 20(2): 217-235.

Kącki Z., Dajdok Z. \& Szczęśniak E. (2003): Czerwona lista roślin naczyniowych Dolnego Śląska. 9-65 pp. In: Kącki Z. (ed): Zagrożone gatunki flory naczyniowej Dolnego Śląska. Instytut Biologii Roślin, Uniwersytet Wrocławski, Polskie Towarzystwo Przyjaciół Przyrody „,pro Natura”, Wrocław, 245 pp.

Křišt'álová V., Chrtek J., Krahulcová A., Bräutigam S. \& Krahulec F. (2010): Populations of species of Pilosella in ruderal habitats in the city of Prague: frequency, chromosome numbers and mode of reproduction. - Preslia 82: 437-464.

Kurzac M., Wylazłowska J. \& Olaczek R. (2013): Dąbrowa Świetlista w Pernie. 64-66 pp. In: Kurowski J.K. (ed.): Obszary Natura 2000 w województwie łódzkim. Regionalna Dyrekcja Ochrony Środowiska w Łodzi, Łódź, 184 pp.

Kwiatkowski P. (2000): Notatki florystyczne z Gór Kaczawskich i ich Pogórza (Sudety Zachodnie). - Fragm. Florist. Geobot. Polon. 7: 105-116.

- (2015): Notatki florystyczne z Rudaw Janowickich (Polska południowo-zachodnia). Cz. I. - Fragm. Florist. Geobot. Polon. 22(1): 23-33.

Matuszkiewicz W. (2008): Przewodnik do oznaczania zbiorowisk roślinnych Polski. Wydawnictwo Naukowe PWN, Warszawa, 537 pp.

Mirek Z., Piękoś-Mirkowa H., Zając A. \& Zając M. (2002): Flowering plants and pteridophytes of Poland, a checklist. W. Szafer Institute of Botany, Polish Academy of Sciences, Kraków, 442 pp.

Oklejewicz K., Cencora A., Wolanin M., Marciniuk J., Marciniuk P. \& Scelina M. (2013): Nowe i rzadkie gatunki we florze Bieszczadów. - Roczniki Bieszczadzkie 21: 74-80.

Pliszko A. (2014): Flora roślin naczyniowych Pojezierza Zachodniosuwalskiego. - Prace Botaniczne 48: 1349.

Smoczyk M. (2010): Rzadkie i zagrożone rośliny naczyniowe Pogórza Orlickiego (Sudety Środkowe) - część 1. - Przyroda Sudetów 13: 53-70.

Szeląg Z. (2000): Rośliny naczyniowe Masywu Śnieżnika i Gór Bialskich. - Fragm. Florist. Geobot. Polon., Suppl. 3: 1-255.

Zając A. 1978. Założenia metodyczne „Atlasu rozmieszczenia roślin naczyniowych w Polsce”. - Wiad. Bot. 22(3): 145-155.

Zając A. \& Zając M. (eds) (2001): Distribution atlas of vascular plants in Poland. Laboratory of Computer Chorology, Instutite of Botany, Jagiellonian University, Kraków, 714 pp.

Zając M. \& Zając A. (2009): The geographical elements of native flora of Poland. Laboratory of Computer Chorology, Instutite of Botany, Jagiellonian University, Kraków, 94 pp.

Zarzycki K. \& Szeląg Z. (2006): Red list of the vascular plants in Poland. 9-20 pp. In: Mirek Z., Zarzycki K., Wojewoda W. \& Szeląg Z. (eds): Red list of plants and fungi in Poland. W. Szafer Institute of Botany, Polish Academy of Sciences, Kraków, 99 pp.

Zarzycki K., Trzcińska-Tacik H., Różański W., Szeląg Z., Wołek J. \& Korzeniak U. (2002): Ecological indicator values of vascular plants of Poland. W. Szafer Institute of Botany, Polish Academy of Sciences, Kraków, 184 pp.

Author's address: Artur Pliszko, Department of Plant Taxonomy, Phytogeography and Herbarium, Institute of Botany, Jagiellonian University in Kraków, Kopernika 31, 31-501 Kraków, Poland.

E-mail: artur.pliszko@uj.edu.pl 